Article

\title{
Net-Metering and Self-Consumption Analysis for Direct PV Groundwater Pumping in Agriculture: A Spanish Case Study
}

\author{
Alvaro Rubio-Aliaga ${ }^{1}$ (D), Angel Molina-Garcia ${ }^{1, *}$ (D) and M. Socorro Garcia-Cascales ${ }^{2}$ \\ and Juan Miguel Sanchez-Lozano ${ }^{3}$ (D) \\ 1 Department of Electrical Engineering, Universidad Politécnica de Cartagena, 30202 Cartagena, Spain; \\ alvaro.rual@gmail.com \\ 2 Deptartment of Electronics, Computer Technology and Projects, Universidad Politécnica de Cartagena, \\ 30202 Cartagena, Spain; socorro.garcia@upct.es \\ 3 Centro Universitario de la Defensa, Universidad Politécnica de Cartagena, 30720 Murcia, Spain; \\ juanmi.sanchez@cud.upct.es \\ * Correspondence: angel.molina@upct.es; Tel.: +34-968-32-5462
}

Received: 28 February 2019; Accepted: 9 April 2019; Published: 20 April 2019

\begin{abstract}
International policies mainly that are focused on energy-dependence reduction and climate change objectives have been widely proposed by most developed countries over the last years. These actions aim to promote the integration of renewables and the reduction of emissions in all sectors. Among the different sectors, agriculture emerges as a remarkable opportunity to integrate these proposals. Indeed, this sector accounts for $10 \%$ of the total greenhouse gas (GHG) emissions in the EU, representing $1.5 \%$ of gross domestic product (GDP) in 2016. Within the agriculture sector, current solutions for groundwater pumping purposes are mainly based on diesel technologies, leading to a remarkable fossil fuel dependence and emissions that must be reduced to fulfill both energy and environmental requirements. Relevant actions must be proposed that are focused on sustainable strategies and initiatives. Under this scenario, the integration of photovoltaic (PV) power plants into groundwater pumping installations has recently been considered as a suitable solution. However, this approach requires a more extended analysis, including different risks and impacts related to sustainability from the economic and energy points of view, and by considering other relevant aspects such as environmental consequences. In addition, PV solar power systems connected to the grid for groundwater pumping purposes provide a relevant opportunity to optimize the power supplied by these installations in terms of self-consumption and net-metering advantages. Actually, the excess PV power might be injected to the grid, with potential profits and benefits for the agriculture sector. Under this scenario, the present paper gives a multidimensional analysis of PV solar power systems connected to the grid for groundwater pumping solutions, including net-metering conditions and benefit estimations that are focused on a Spanish case study. Extensive results based on a real aquifer (Aquifer 23) located in Castilla La Mancha (Spain) are included and discussed in detail.
\end{abstract}

Keywords: economic-energy-environment (3E) analysis; solar pumping; renewable energy source (RES) integration; net-metering; sustainable rural development

\section{Introduction}

Presently, the sustainability of the globalized society is at potential risk because of climate change, involving an important level of atmospheric pollution. These environmental effects have been evidenced in the climate and in the availability of natural resources, mainly water. With respect to this 
resource, the growing water demand requires government support to avoid undesired overexploitation. In addition, climate change can affect all sectors of society. In fact, certain effects are beginning to cause concern in the agricultural sector, such as minor rainfalls and increasing temperatures. These impacts also affect the sustainability of this sector as well as other dimensions, such as energy and productivity, and finally end up affecting the social and economic global structure, especially in rural areas and areas with water scarcity. To overcome these negative impacts, international organizations have promoted several agreements as global strategies, such as the Kyoto Protocol and the COP21 Conference of the Parties on Climate Change held in Paris in 2015 [1], aiming to reduce the impacts of those climate changes. At this last event, it was agreed to contain the increase in global average temperature below $2{ }^{\circ} \mathrm{C}$ at the end of the current century. To fulfill this objective, different actions were proposed, mainly focused on (i) reducing dependence on fossil fuels; (ii) increasing the integration of renewable energy sources [2]; and (iii) decreasing $\mathrm{CO}_{2}$ emissions into the atmosphere. The change in the energy model toward a major use of renewable energy resources within a framework of sustainable development in all economic sectors of society implies the need for a firm Research and Development and Innovation $(\mathrm{R}+\mathrm{D}+\mathrm{i})$ strategy. Although solutions to achieve these targets in the domestic, industrial, and transport sectors have been widely studied, there is a lack of contributions for the agriculture sector, which requires a more detailed and multidimensional analysis. Actually, from an agro-energy perspective, this issue must be studied widely in a global analysis on the environmental, hydrological, and socioeconomic effects that have certain influences on pumping irrigation. Therefore, the energy demand and proposals for renewable energy alternatives must be considered in all applications of agriculture, and specifically in pumping facilities. Villamayor-Tomas affirms that remaining institutional challenges must include an important water rights reform, including the promotion of a distributed energy network and irrigation modernization within Spain and at the European level [3]. The change in the energy model of pumping agriculture thus represents a strategy to reduce dependence on fossil fuels, creates wealth in rural areas, settles employment, and allows participation in the reduction of $\mathrm{CO}_{2}$ emissions. Photovoltaic (PV) solutions for agriculture pumping present a viable and profitable alternative to replacing diesel generators in isolated and individual installations [4-6]. This has mainly been motivated by high fuel costs and easily amortized investment costs. In fact, Cuadros et al. defines 'photoirrigation' as a procedure to estimate PV installations for irrigation pumping purposes [7]. Some significant agriculture-energy synergy studies have been conducted by different authors [8-10]. However, most contributions in the agricultural sector are focused on standalone solutions without considering distributed generation purposes. In this way, battery and water tanks are proposed in [11] to store energy obtained from solar panels increasing the system stability. Mohana Rao et al evaluate PV-based water pumping system for agricultural sector under standalone conditions [12]. Similar analysis can be found in [13,14], where standalone PV water pumping systems described and evaluated. Binshad et al. investigates the operation and analysis of the photovoltaic water pumping system without considering grid connection requirements [15]. A grid-connected hybrid renewable energy system example is described in [16], consisting of PV and wind power technologies applied on rural township in the Mediterranean climate region of central Catalonia (Spain). Therefore, there is a lack of contributions focusing on grid-connected PV pumping systems for water supplies and human consumption where self-consumption and net-metering schemes are evaluated. This lack of contributions thus implies that $(i)$ analysis of global irrigation pumping is not available in the specific literature; (ii) these solutions depend on different variables that must be evaluated accordingly; and (iii) PV pumping solutions need to be analyzed annually to include the problem of low use of these PV installations depending on the crops. In fact, optimal use and exploitation of the facility should be properly evaluated. Moreover, it is necessary to analyze energy generated in periods when irrigation is not demanded by crops and periods when an excess of PV generation power is provided by the installation. Some studies confirm that PV installations are usually oversized for individual PV solar pumping solutions [17], which are used for irrigation purposes only 180-200 h per year. In most cases, for the rest of the potential PV solar 
hours, when energy is available from their locations, PV power plants are disconnected from the grid and this additional energy is not used as a potential resource. For this reason, the use of this surplus energy, which in some cases could reach $80-90 \%$ of the annual potential energy generated by the PV system, must be analyzed in detail. In this way, Langarita et al. affirm that in irrigated agriculture, a producer-consumer can be systematically exposed to energy shortfalls and surpluses [18]. An example of hybrid power plant with wind turbines, photovoltaic panels, and compressed air energy storage is described in [19], where positive income due to sale of surplus energy to the national power grid is analyzed.

Presently, the idea of systems organized in agro-smart grids or rural smart grids, conceived as distributed generation in rural areas, has been widely studied [20-23]. This organizational structure represents an alternative way of carrying out energy development integration, energy storage, automation, measurement systems, information, and communication related to power generation/demand. In addition, it provides not only better and more efficient distribution/production energy management [24], but also an optimal localized use of resources $[25,26]$. This concept also includes efficient water management, automation, and precision agriculture, and generation/demand balance in rural areas. Figure 1 summarizes schematically the integration of the agricultural sector into a smart grid. However, one of the main limitations of these solutions is the power line construction cost and the auxiliary elements to inject the power from those PV power plants to the grid. Moreover, Bassi affirms that it is difficult to connect millions of scattered wells, fitted with solar pumps (earlier operating with diesel pumps), to the power grid [27]. Another important drawback of these systems in general—including other sectors such as the residential sector [28]—is the current legislation and requirements on distributed generation and net-metering policies. Christoforidis et al. affirm that there is a lack of a universal policy harmonizing the respective legislations of the EU member countries in terms of net-metering schemes [29]. Nevertheless, there is a favorable legislative framework for this type of facility in some countries such as Belgium and Denmark, in other countries, such as Spain, there is currently no advantageous regulation for net-metering implementation [30]. For the Spanish case, and after a long series of changes in the regulatory and legal framework of renewable energy installations in Spain (RD1699/2011, RDL 1/2012, L15/2012, OM1491/2013, RD413/2014), the regulation of self-consumption and net-metering facilities through RD900/2015 [31] implies a series of taxes that must be paid by the facilities connected to the grid when they inject power into the grid. Further information focused on self-supply and net-balance Spanish policies can be found in [32].

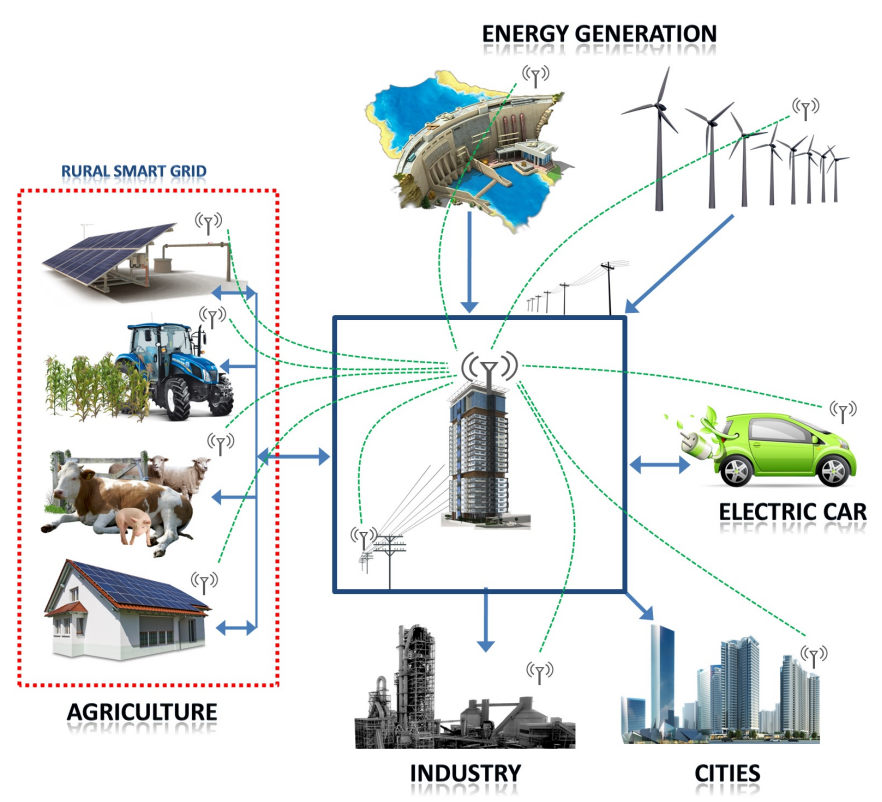

Figure 1. Integration of the agricultural sector into a smart grid: supply and demand-side active roles. 
By considering previous contributions and the lack of analysis from a multidimensional perspective regarding PV power plants connected to the grid for groundwater pumping solutions, this paper aims to:

- Analyze and identify, from a socioeconomic, environmental, and energy perspective, the problems of current agriculture groundwater pumping systems based on fossil fuel technologies.

- $\quad$ Propose and analyze PV solar pumping alternatives connected to the grid by including surplus energy and its injection into the grid, evaluating the possible economic profits from the sector.

- Evaluate a case study based on including this alternative in a real environment and crops located in the southeast of Spain (Castilla La Mancha Region).

The rest of the paper is structured as follows: Section 2 discusses the methodology, focused on a global analysis of the problem in agriculture, describing the problems and their most important impacts, as well as the process of determining the surplus energy and the possible economic return from the sale of such additional energy. Section 3 describes the case study. Results are given in Section 4, including estimations of the surplus energy and the potential economic benefits of the sale of energy. In addition, benefits provided to the agriculture sector with the integration of this solar resource are also included. Finally, conclusions are given in Section 5.

\section{Multifocused Analysis Methodology}

The proposed methodology can be divided into two parts. The first part is a preliminary approach focused on analyzing, from a multidimensional perspective, the energy problem of groundwater pumping for agriculture. In this way, a study that considers a relevant number of specific factors, derived in part from the current use of fossil fuel-based solutions usually implemented for irrigation purposes, is conducted by the authors. We analyze how future changes related to an upcoming energy model, through the implementation of renewable resources (mainly PV technology as proposed this work), can address relevant positive impacts on the agriculture sector. The second part of the methodology describes a process for characterizing the energy alternative of PV pumping installations connected to the grid, identifying and quantifying the benefits provided by this solution [33]. Figure 2 schematically summarizes the proposed methodology.

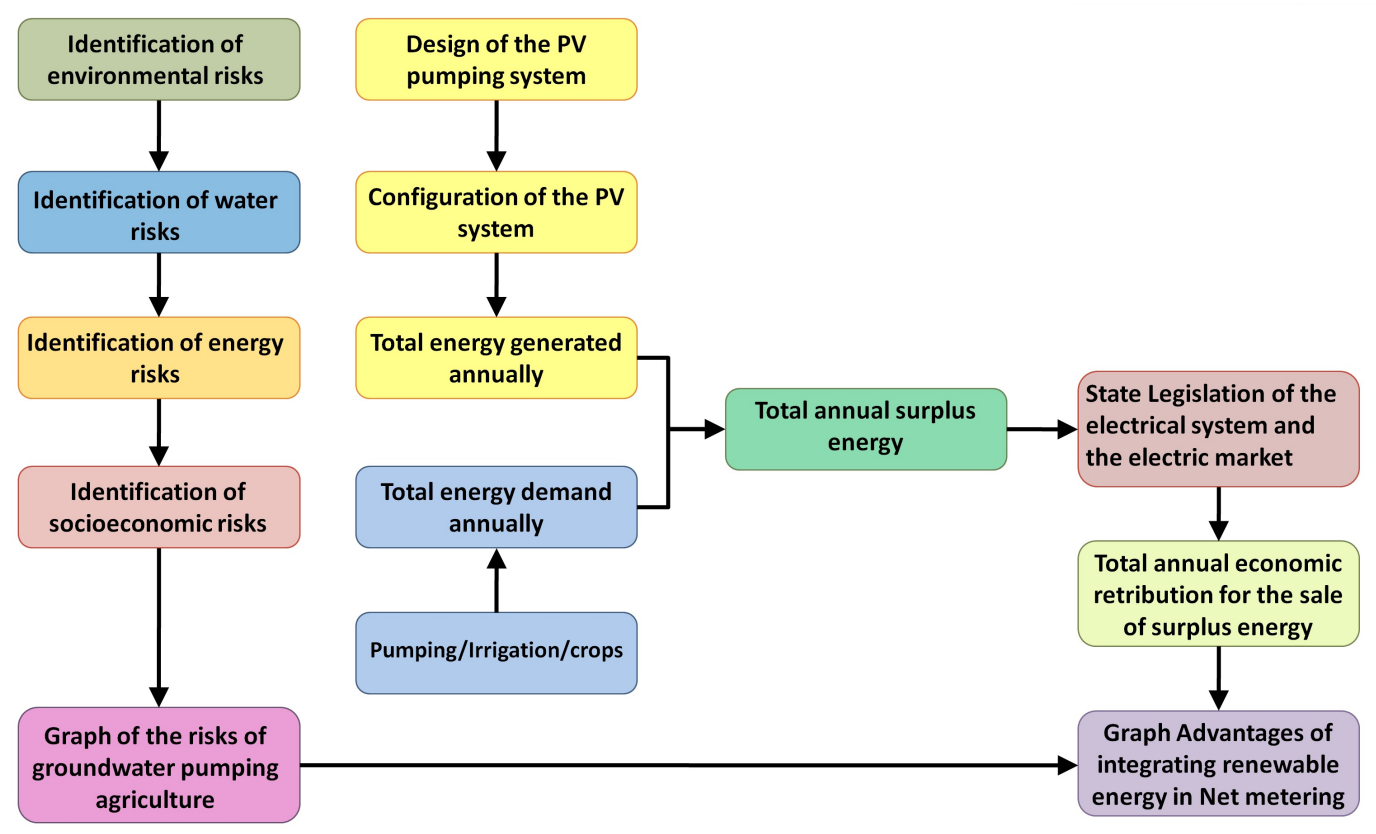

Figure 2. Description of the proposed methodology. 


\subsection{Groundwater Agriculture Problem: Multifocused Analysis}

A multidimensional analysis is proposed by the authors to characterize groundwater pumping in agriculture. With this aim, the problem is analyzed considering: (i) an environmental problem (climate change, rainfall, temperature); (ii) a water scarcity problem (decreased aquifer phreatic level, among others); (iii) an energy problem; and (iv) a socioeconomic problem. Figure 3 shows this multidimensional analysis and the relationships among the different points of view. This methodology is in line with other contributions. Moreover, the proposed methodology considers some aspects that have been neglected or not considered in other works. Actually, the problem of sustainability related to water and aquifer resource exploitation as well as PV solar installation analysis has been previously considered in [34-37]. Figure 3 summarizes the dependencies and influences among the different approaches, which are discussed in detail below.

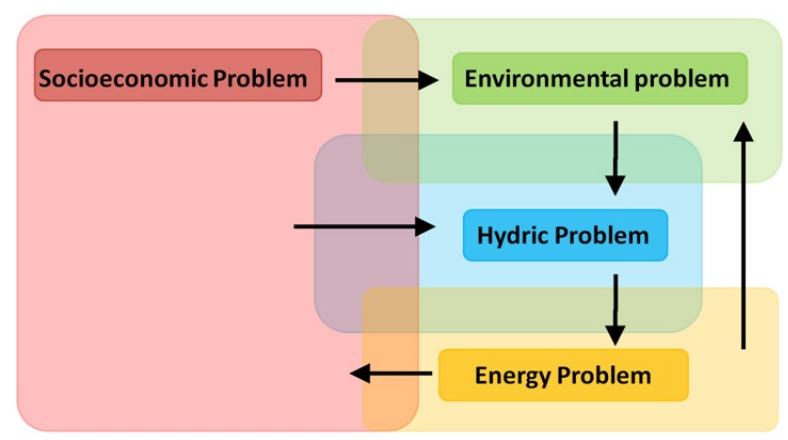

Figure 3. Multifocused analysis for agriculture groundwater pumping purposes.

\subsubsection{Environmental Analysis}

The environmental problem emerges as one of the most crucial impacts. In fact, this issue can involve important problems for the agricultural sector and its irrigation requirements, especially for groundwater irrigation proposals. In an arid climate, climate change can lead to a decrease in precipitation, consequently reducing the natural recharge of aquifers. These negative conditions are a limiting factor for agricultural development in those areas of the world [38]. Reduced rainfall as a result of climate change is not the only environmental impact, but also rising temperatures and other collateral effects. In fact, some analyses and studies focused on climate forecasting suggest a gradual temperature increase, with warmer and drier summer periods. Therefore, water reservoirs and lakes exposed to solar radiation can lose more water by evaporation, and crops will demand greater amounts of water. From a climate perspective, analysis of these data shows a clear tendency from semiarid areas to severely arid conditions, almost becoming desertified areas.

Water resource management in the agriculture sector emerges as a crucial and relevant factor, affecting irrigation and slightly increasing crop water requirements. Desertification and soil erosion are then collateral problems as a result of poor agricultural practices and inefficient use of irrigation strategies, leading to the loss of soil moisture in semiarid areas. Presently, the climate change problem is leading to unsustainability due to the overexploitation of some aquifers. Other physicochemical problems have also been identified as a consequence of such overexploitation. Leachates, pesticides, and inorganic fertilizers can come into contact with the aquifer and produce a contaminated environment. As an additional drawback to the overexploitation problem, groundwater salinization is becoming extreme. Consequently, water is unusable for either agriculture or human consumption unless highly expensive pretreatment is carried out. Finally, $\mathrm{CO}_{2}$ emissions produced by pumping irrigation in agriculture must be also estimated and analyzed. Traditional agriculture has mostly been based on diesel equipment. Obviously, these systems do not contribute to mitigating climate change effects, but increase emissions. Therefore, alternative solutions based on clean and renewable energy technologies in the agriculture sector can promote the reduction of emissions. 


\subsubsection{Water Analysis}

As previously discussed, climate change has an important impact on pumping solutions and it must be considered for irrigation groundwater purposes. In fact, well-irrigated areas have increased rapidly over the last century thanks to a large investment in pumping technology. Thanks to advances in irrigation technology, farmers have changed their agricultural models from rainfed lands (with a low agricultural productivity ratio) to high-yield irrigated crops. Indeed, some of these crops have a very high water demand, such as maize, beets, and rice. Therefore, these advances have given farmers a remarkable opportunity to diversify their crops for greater economic value but also higher water demand value, by increasing pressure on aquifers [39].

Concerns about groundwater sustainability became relevant when many aquifers reached overexploitation and encountered emergency situations [40]. Overexploitation of aquifers also involves direct environmental impacts on discharges or sources [41,42]. Indeed, sources and rivers dependent on aquifers have considerably reduced their flows, generating problems downstream of the aquifers, for both irrigation and human consumption purposes. At the same time, lake and fluvial aquatic ecosystems have been degraded, depending on maintenance of the phreatic level. Examples of these situations can be found in the Tables of Daimiel (Spain), the Saiss plain (Morocco), the flow losses of the Mikkes River, and other sources [43]. Overexploitation and other water problems are transformed into greater energy demands. Irrigation methods present different efficiency values, with significant discrepancies among them. For example, methods based on gravity, furrows, or flooding are the most inefficient irrigation solutions (50\%). Apart from water inefficiency, their use can bring serious consequences to underground aquifers [44]. To achieve suitable crop maintenance, a more efficient use of water resources should be proposed, such as localized irrigation ( $90 \%$ efficiency) or irrigation by spraying (70-80\%) [45]. In addition to the previous problems, which are easily discernible by their immediate impact on the agricultural economy, other problems associated with the continuous depletion of aquifer resources can be identified, such as the problematic subsidence of the terrain due to different pressures of water storage inside [46].

\subsubsection{Energy Analysis}

The environmental issues not only affect the water balance of the river basins, but are also involved in one of the main water problems in agriculture: aquifer overexploitation with high energy consumption [47]. Once a well is built, the energy required to raise water to the surface is the most relevant annual cost for these systems. This cost depends mainly on: (i) the unit price of energy, (ii) the depth of the phreatic level, (iii) the generator-pump system efficiency, and (iv) the hydrogeological characteristics of the aquifer. The high energy dependence of fossil fuels poses an international problem for any sector, and it usually involves high costs. The agriculture sector also suffers from these consequences, as it is a demanding sector of fossil fuels. To solve this, geopolitical and economic factors must be considered to find a suitable solution. For a specific crop, a decreasing phreatic level is closely related to the corresponding energy requirements. Indeed, proper hydric maintenance requires pumping from a deeper source of water and thus more energy is required in the process. Reducing the phreatic level requires a large amount of energy to raise, transport, and distribute water to crops. Increased energy demand involves major production costs for farmers, regardless of their country. This is a difficult problem to be borne by farmers, since it implies more economic effort to pay for fuel for pumping. Different contributions have been devoted to solving this energy problem [48]. The different solutions depend on proper water management to meet high energy demands at low cost [49]. Other inefficiencies, such as poorly performing irrigation methods, a lack of maintenance, or oversized facilities, can mean an excess of energy demand and high economic costs. To solve these problems, some countries have developed different energy policies for agriculture, aiming to reduce the cost of energy production. In some cases, national policies advocate the subsidization of fossil fuels for any sector or exclusively focused on agricultural use. Other policies are based on fiscal subsidies 
of hydrocarbon taxes on farmers and ranchers, whereas in other countries, the price of fuel is totally regulated by the government.

\subsubsection{Socioeconomic Analysis}

The problems mentioned above usually imply an increasing price of fuels to meet the relevant energy demand. Because of this, small plots with wells are disappearing and the current tendency is to aggregate larger areas able to decrease the costs associated with pumping maintenance at very deep groundwater levels. This effect is the complete opposite of maintaining traditional agriculture and land democratization [50]. The typical way of dealing with this problem is to raise food prices by farmers; usually prices at the farmer level are then increased to improve their profit margin. This option reduces the competitiveness of their products compared to similar and cheaper products from other countries where the costs of production are considerably lower [50]. A more drastic option is to give up crops or plots, which results in poor economic benefits and does not allow this solution to continue over time. This last option generates depopulation in agricultural and rural areas, where the opportunities and jobs could decrease drastically [50]. Both options have a great impact on the agricultural sector, involving a loss of economic value in the sector, a loss of competitiveness for national products, a reduction in investment, and a subsequent loss of plot value in rural areas. In addition, there is a loss of social value, such as loss of employment in the countryside, loss of traditional agriculture, and depopulation of rural areas. These situations mean that governments, including international associations such as the European Union and the United Nations Organization, must offer alternative actions, strategies, and energy policies to provide solutions to these problems. These strategies are intended to help or subsidize the agricultural sector, such as the Community Agricultural Policy (CAP), which subsidizes, with nuances, such loss of competitiveness of European products directly to farmers. In other cases, there is protectionism toward national agriculture, such as an agrarian policy.

\subsection{PV System Configuration and Surplus Energy Estimation}

Presently, customers of electricity that have installed energy sources at their households are transformed into 'prosumers' [51]. As was previously discussed, different countries use diverse schemes of support for 'prosumers' [52]. In fact, diverse mechanisms supporting the self-consumption of electricity in key countries all over the world and to highlight the challenges and opportunities associated with their developments have been recently discussed by the IEA [53]. Under this framework, the present section characterizes the sale of energy from PV installations, which supplies energy for agricultural irrigation by groundwater. This characterization process starts with an initial database, where the energy demanded by the irrigated area and the energy-demanding facilities are estimated. Subsequently, a preliminary configuration of the PV facility is determined by including the type of technology (Mono-Si, Te-Cd...), solar tracking options, connection to the grid, and injection of surplus energy to the grid. Other parameters such as depth of the aquifer, plot grouping, and water needs of crops are also taken into account [9]. It is then possible to estimate the rate power of the PV installation under different groundwater pumping scenarios, which depend on the depth of the aquifer level, the averaged crop water demand, and the hydraulic system pressure. For the purpose of comparing different alternatives, the rate power required by the pump is first estimated $\left(P_{p}\right)$ [54]:

$$
P_{p}=\frac{H_{t} \cdot Q_{m x} \cdot \rho \cdot g}{v_{M P}} \rightarrow P_{d}=\frac{P_{p} \cdot K_{d}}{v_{d}} \rightarrow P_{g}=P_{d} \cdot K_{g}
$$

where $H_{t}$ is the total dynamic head (m), $Q_{m x}$ is the maximum flow rate $\left(\mathrm{m}^{3} / \mathrm{s}\right), r$ is the water density $\left(\mathrm{kg} / \mathrm{m}^{3}\right), g$ is the earth's gravitational acceleration $\left(\mathrm{m} / \mathrm{s}^{2}\right)$, and $v_{M P}$ is the pump efficiency (\%). For PV solar power estimations $\left(P_{P V}\right)$, the following expression is proposed [55]:

$$
P_{P V}=\frac{E_{d e m}}{E_{(\alpha, \beta)} \cdot P R}
$$


where $E_{d e m}$ is the expected averaged energy consumption ( $\mathrm{kWh} /$ day) by considering the crop water need, $E_{(\alpha, \beta)}$ is the expected averaged energy production of a PV power plant from an average monthly value of a typical daily irradiation on the horizontal surface $\left(\mathrm{kWh} / \mathrm{m}^{2}\right.$. day) and $P R$ is the performance ratio of the PV installation. The surplus energy from the PV pumping system can be then determined from the global PV-generated power and the global crop water need:

$$
S e_{(x, y, z)}=\sum_{k=1}^{k=8760} \frac{E_{g e n}(k)-E_{d e m}(k)}{1000}
$$

where $S e_{(x, y, z)}$ is the surplus annual energy (MWh/year), $x$ is the aggregated areas (ha), $y$ is the phreatic level of groundwater depth $(\mathrm{m}), z$ the global crop water need $\left(\mathrm{m}^{3}\right), k$ is hours in a year, $E_{\text {gen }}$ is the energy produced in a specific $k$-hour $(\mathrm{kWh})$, and $E_{d e m}$ is the energy demanded in a specific $k$-hour (kWh).

The next step is to apply the rules and requirements to enable pouring surplus energy into the electricity grid, determining the economic values to consider possible economic retribution. At this point, as discussed in the introduction, the net-metering is differentiated by applying the prices of the electricity market and self-consumption defined and regulated by the corresponding national authorities. The following section describes the case study, which focuses on current Spanish legislation. Nevertheless, the proposed methodology can also be applied to other legislative frameworks under different national authority requirements.

\section{Case Study}

\subsection{Preliminaries}

Recently, Barbel affirms that in Spain, irrigated agriculture accounts for $20 \%$ of the total agricultural area, consumes $75 \%$ of total water resources, and generates $60 \%$ of the total agricultural production and $80 \%$ of agricultural exports [56]. Under these circumstances, Aquifer 23 located in Castilla La Mancha, Spain, is considered for the case study. Figure 4 shows the location of this aquifer and the agricultural area that depends on this water resource. The area is basically a sedimentary basin immersed in a karstic system. This aquifer varies in depth between 10 and $70 \mathrm{~m}$, occupying an area of $5500 \mathrm{~km}^{2}$. Recently, it has been declared an overexploited aquifer as a consequence of not only poor management and a lack of environmental and water control, but also a lack of planning of water resources. Indeed, it has reached drops of $2.3 \mathrm{~m} /$ year over several years of severe extraction. Over the last decade, it has been considered as a remarkable resource recovery example, increasing the groundwater level of the aquifer, as depicted in Figure 5. Presently, this aquifer is still considered overexploited, mainly due to high influence of recent periods of low rainfall. The recovery process is a consequence of the awareness of this situation and farmers' economic dependence on the aquifer [57]. Irrigation is one of the main economic drivers and sources of sustenance of the rural society in this area [58]. Regarding the climate in the area, it can be classified as continental Mediterranean with dry and hot summers with high solar irradiance levels, and cold winters with certain frost periods. Spring and autumn are characterized by soft and humid periods. Annual rainfall is a determining factor, which in the study area presents relevant oscillations between wetter periods and drier periods, accounting for 350-400 mm per year. However, with the conditions imposed by climate change in recent decades, average annual temperatures are slightly rising while rainfall is being partially reduced, posing a serious risk of desertification. Solar resource has high average potential during sunshine hours, with more than 4900 sunshine hours per year. Figure 6 depicts solar irradiance levels and aquifer depth for the case study. 

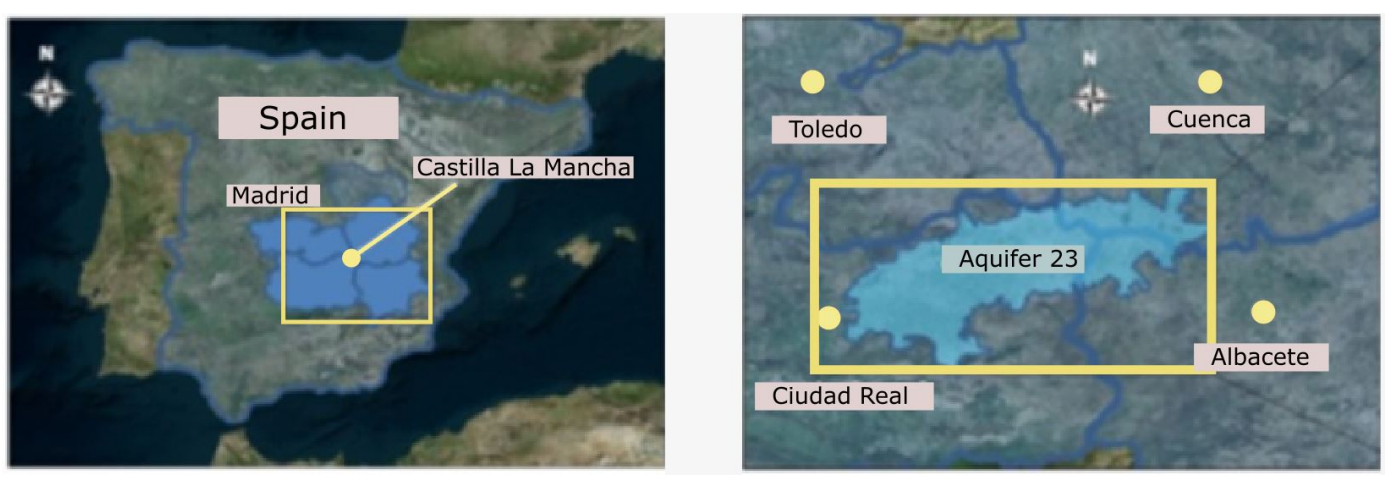

Figure 4. Location of study area and aquifer.
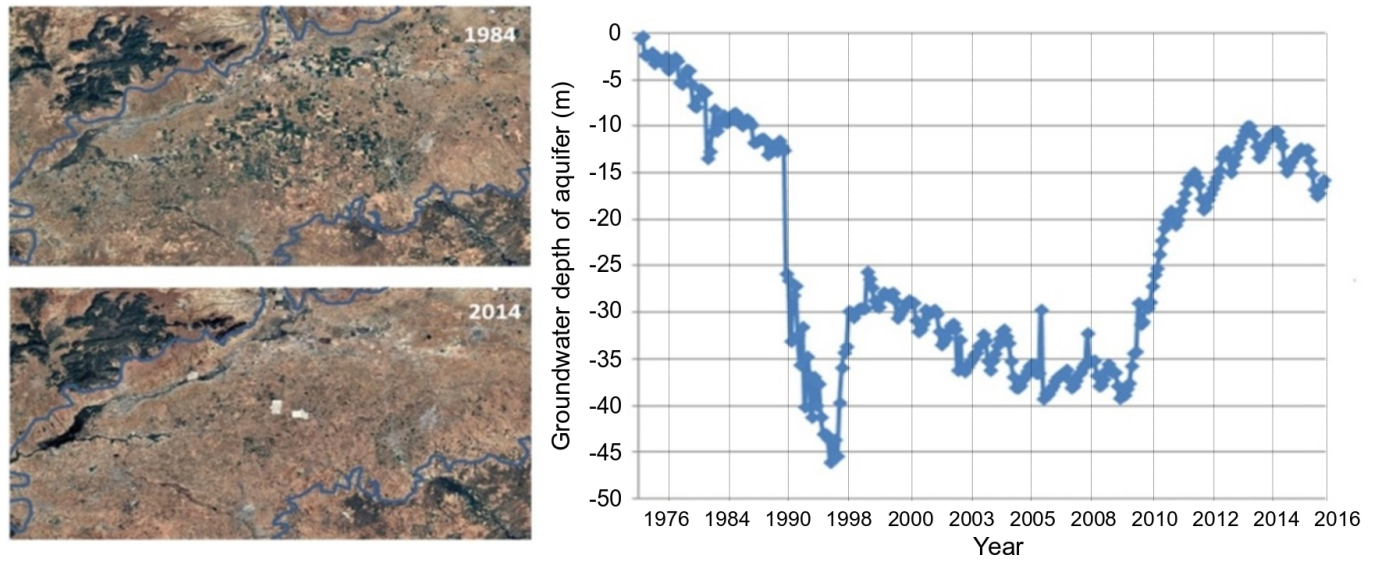

Figure 5. Satellite image of regime of exploitation of water resources and chronological graph of groundwater aquifer level. Source: Authors' elaboration through Google Earth images and CHG data.
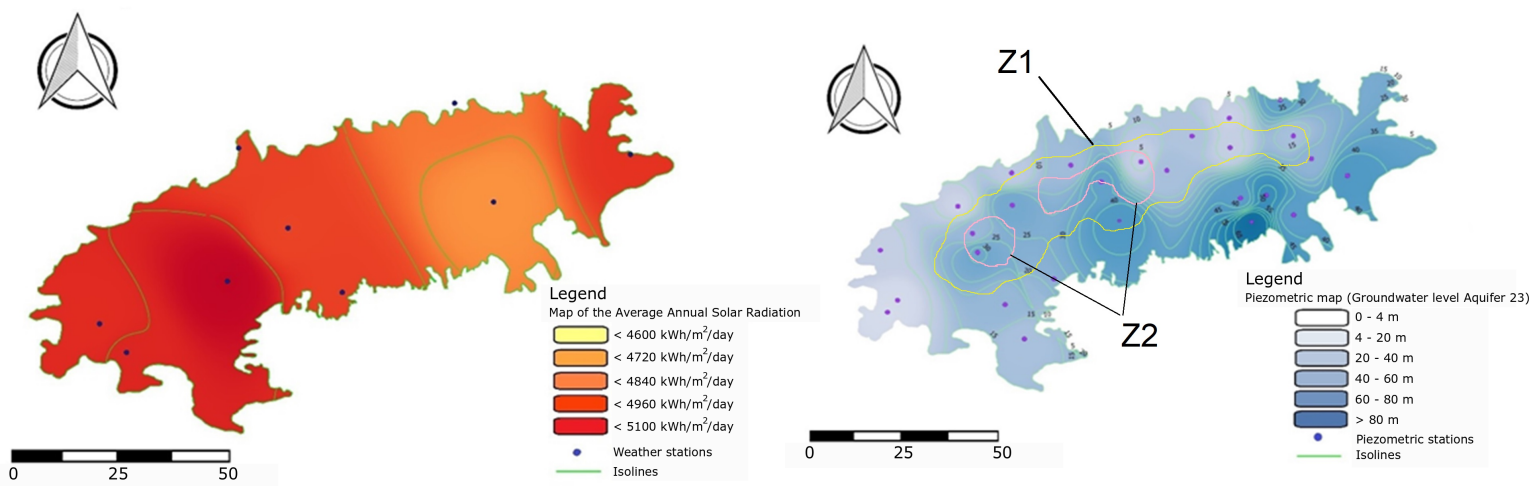

Figure 6. Irradiance solar resource and groundwater depth level: case study. Description of Z1 and Z2.

\subsection{Crop Water Need}

According to Figure 6, the central band of the aquifer (labelled as Z1) has the highest concentration of irrigation plots: $79 \%$ of the irrigation surface of the entire aquifer. This part accounts for 257,456 ha and $58 \%$ of this surface $(149,647$ ha) has irrigated crops. In other areas, labelled as Z2, groups of plots have an irrigated vs. unirrigated ratio of around $75 \%$, accounting for around $15 \%$ of the agricultural surface on the global aquifer. In addition, the average depth of the aquifer estimated in 2016 was $29.41 \mathrm{~m}$, according to reference piezometers used by the Guadiana Hydrographic Confederation (Spain) and data from the SIG maps. Due to the initial conditions related to the present case study, two levels of crop water need are considered: $1500 \mathrm{~m}^{3} /$ ha per year and $3000 \mathrm{~m}^{3} /$ ha per year. Both values are the result of water constraints on crop irrigation with the aim of preserving the aquifer. Although there are crops that have higher water requirements, most crops in the study area (mainly vineyards) currently have an average water requirement within the selected range, by considering usual and real 
grouping plots. Subsequently, both crop water need values $\left(1500 \mathrm{~m}^{3} /\right.$ ha and $3000 \mathrm{~m}^{3} /$ ha per year) are representative of averaged crop irrigation necessities.

\subsection{PV Power Plant Configuration}

As was previously described in Section 2.2, the rate power of the PV installation can be estimated by considering the depth of the aquifer level, the averaged crop water demand and the aggregated crop area. Under these requirements, the specific PV power plant configuration is not in line with usual individual installations, mainly promoted in the agricultural sector and based on isolated pumping systems. In our case, we propose an aggregated PV pumping solution without accumulation, directly connected to the grid and excluding any water reservoir facility. The proposed pumping solution thus requires more power, but lower annual maintenance. Therefore, PV power plant solutions with PV modules based on mono-silicon PV technology in fixed installations is considered for the analysis, being the rate PV power estimated to cover the average daily demand according to a specific crop water need. From the aquifer characteristics, ranges to be considered for the study can be then summarized as follows: groups from 1 to 2000 ha, groundwater pumping levels between 10 and $55 \mathrm{~m}$ of aquifer depth; and two representative crop water need: $1500 \mathrm{~m}^{3} /$ ha and $3000 \mathrm{~m}^{3} /$ ha-discussed in Section 3.2. Different PV power plant solutions are determined based on the different configurations assumed in the case study. In this way, Figure 7 summarizes the PV solutions (in kWp power capacity) for the different scenarios. In all cases, PV power plant is determined to supply the averaged power demand according to the crop water need, the aggregated area (ha) and groundwater pumping level (m). Therefore, the PV power plants to be installed (in $\mathrm{kWp}$ ) would provide power enough to supply the corresponding pumping groundwater requirements.
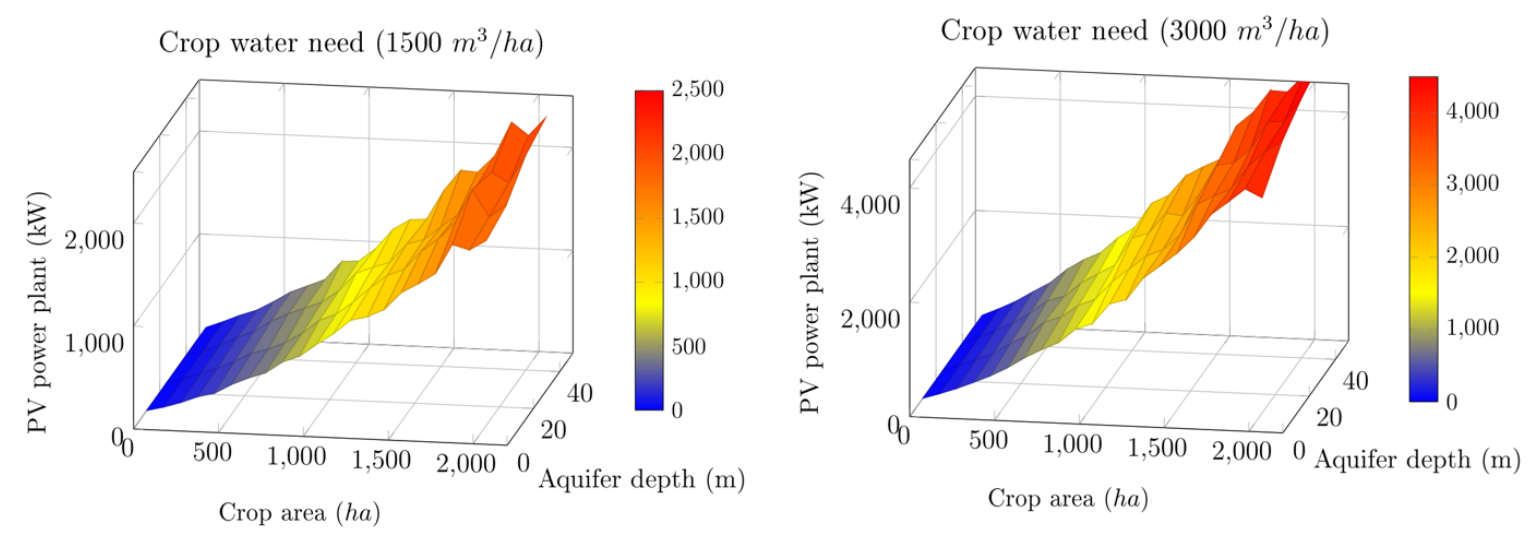

Figure 7. PV power plant capacities for self-consumption scenarios: $1500 \mathrm{~m}^{3} /$ ha and $3000 \mathrm{~m}^{3} /$ ha.

\subsection{Self-Consumption: Spanish Legislative Framework}

As previously discussed, the proposed methodology can be applied to any legislative framework and according to the corresponding different national authority requirements. In our case, the aquifer is in Spain (Aquifer 23), and thus, the Spanish legislation based on RD 900/2015 is applied [31]. Through this directive, two types of self-consumption are defined: (i) Type 1, lower than $100 \mathrm{~kW}$ of rate power; most individual pumping irrigation facilities can be classified as Type 1; and (ii) Type 2 , self-consumption with more than $100 \mathrm{~kW}$ rate power, injected into the grid at a price established by the electricity market pool. In line with the PV power plant capacities estimated and summarized in Figure 7, most communities of solar pumping irrigators would be considered as Type 2. In the case of Spain, taxes and fees that would reduce the final remuneration for the sale of energy must be imposed. These conditions represent a burden at a time of encouraging the implementation of solar solutions-mainly in this case that PV power plants connected to the grid cannot be amortized in a relatively short period of time. Indeed, the costs include a variable charges component associated with the system costs and determined from the variable terms, and a capacity payment component to 
compensate for system support, compensation to the market and system operators, and interrupted service and adjusted service. It is also necessary to add the recent $7 \%$ tax on electricity generation (in September 2018 this was removed by the Spanish government) and the value added tax (VAT) of 21\%. Tables 1-3 summarize the representative Spanish fixed, variable, and additional costs to be currently considered for the sale of energy.

Table 1. Spanish fixed fees and taxes applied to the sale of surplus energy through self-consumption: requirements according to RD900/2015 [31].

\begin{tabular}{lcccccc}
\hline & \multicolumn{7}{c}{ Annual Fixed Tax (Euro/kWh) } \\
\cline { 2 - 7 } Access Cost & Period 1 & Period 2 & Period 3 & Period 4 & Period 5 & Period 6 \\
& P1 & P2 & P3 & P4 & P5 & P6 \\
\hline $2.0(\mathrm{P} \leq 10 \mathrm{~kW})$ & 8.682019 & & & & & \\
$2.1(10 \leq \mathrm{P} \leq 15 \mathrm{~kW})$ & 15.083303 & & & & & \\
$3.0 \mathrm{~A}(\mathrm{P}>15 \mathrm{~kW})$ & 32.083923 & 6.212601 & 14.245468 & & & \\
3.1 A $(1 \mathrm{kV}$ to $36 \mathrm{kV})$ & 35.952537 & 6.717794 & 4.985851 & & & \\
6.1 A $(1 \mathrm{kV}$ to $30 \mathrm{kV})$ & 22.169359 & 7.844864 & 9.790954 & 11.926548 & 14.278122 & 4.882162 \\
$6.1 \mathrm{~B}(30 \mathrm{kV}$ to $36 \mathrm{kV})$ & 14.050921 & 3.782129 & 6.817708 & 8.953302 & 11.304876 & 3.525577 \\
$6.2(36 \mathrm{kV}$ to $72.5 \mathrm{kV})$ & 9.082012 & 1.409534 & 4.372144 & 6.352856 & 8.073738 & 2.442188 \\
$6.3(72.5 \mathrm{kV}$ to $145 \mathrm{kV})$ & 9.279523 & 2.525841 & 3.909548 & 5.479569 & 6.893947 & 1.911493 \\
$6.4(\geq 145 \mathrm{kV})$ & 2.815509 & 0.000000 & 1.718359 & 3.457606 & 4.990376 & 0.970612 \\
\hline
\end{tabular}

Table 2. Spanish variable fees and taxes applied to the sale of surplus energy through self-consumption: requirements according to RD900/2015 [31].

\begin{tabular}{lcccccc}
\hline & \multicolumn{7}{c}{ Annual Variable Tax (Euro/kWh) } \\
\cline { 2 - 7 } Access Cost & $\begin{array}{c}\text { Period 1 } \\
\text { P1 }\end{array}$ & $\begin{array}{c}\text { Period 2 } \\
\text { P2 }\end{array}$ & $\begin{array}{c}\text { Period 3 } \\
\text { P3 }\end{array}$ & $\begin{array}{c}\text { Period 4 } \\
\text { P4 }\end{array}$ & $\begin{array}{c}\text { Period 5 } \\
\text { P5 }\end{array}$ & $\begin{array}{c}\text { Period 6 } \\
\text { P6 }\end{array}$ \\
\hline 2.0 A $(\mathrm{P} \leq 10 \mathrm{~kW})$ & 0.043187 & & & & & \\
2.0 DHA $(\mathrm{P} \leq 10 \mathrm{~kW})$ & 0.057144 & 0.006148 & & & & \\
2.0 DHS $(\mathrm{P} \leq 10 \mathrm{~kW})$ & 0.057938 & 0.006430 & 0.006112 & & & \\
2.1 A $(10 \leq \mathrm{P} \leq 15 \mathrm{~kW})$ & 0.054883 & & & & & \\
2.1 DHA $(10 \leq \mathrm{P} \leq 15 \mathrm{~kW})$ & 0.068081 & 0.015450 & & & & \\
2.1 DHS $(10 \leq \mathrm{P} \leq 15 \mathrm{~kW})$ & 0.068875 & 0.018220 & 0.011370 & & & \\
3.0 A (P $>15 \mathrm{~kW})$ & 0.020568 & 0.013696 & 0.008951 & & & \\
3.1 A $(1 \mathrm{kV}$ to $36 \mathrm{kV})$ & 0.015301 & 0.009998 & 0.012035 & & & \\
6.1 A $(1 \mathrm{kV}$ to $30 \mathrm{kV})$ & 0.011775 & 0.011336 & 0.007602 & 0.009164 & 0.009986 & 0.006720 \\
6.1 B $(30 \mathrm{kV}$ to $36 \mathrm{kV})$ & 0.011775 & 0.008312 & 0.007322 & 0.008260 & 0.009403 & 0.006349 \\
6.2 (36 kV to 72.5 kV) & 0.012669 & 0.011554 & 0.007881 & 0.008377 & 0.008716 & 0.006245 \\
6.3 (72.5 kV to $145 \mathrm{kV})$ & 0.015106 & 0.012816 & 0.008530 & 0.008510 & 0.008673 & 0.006278 \\
6.4 $(\geq 145 \mathrm{kV})$ & 0.011775 & 0.008531 & 0.007322 & 0.007788 & 0.008257 & 0.006104 \\
\hline
\end{tabular}

Table 3. Spanish additional fees and taxes applied to the sale of surplus energy through self-consumption: requirements according to RD900/2015 [31].

\begin{tabular}{lc}
\hline \multicolumn{2}{c}{ Annual Additional Tax (Euro/kWh) } \\
\hline Electricity market operation & 0.000025 \\
Power system operation & 0.000109 \\
Interruptibility service & 0.002000 \\
Provision of adjustment services & 0.003210 \\
\hline
\end{tabular}

In Spain, the times of reduced power are usually distributed in three periods. However, for power higher than $450 \mathrm{~kW}$, the Spanish electricity market offer six time periods (P1, P2, P3, P4, P5, P6). Figure 8 shows the electricity rates for the different time periods under the Spanish electricity system legislation. As an example, and for the systems described in this case study (direct PV solar pumping installations) and the selected crop water-need values- $1500 \mathrm{~m}^{3} /$ ha and $3000 \mathrm{~m}^{3} / \mathrm{ha}$, the typical periods for this 
type of facility are the following: P5 in May, P3 and P4 in June, P1 in the rest of June and July, and P6 in August. Irrigation is not usual in September for the considered crops, but it would be framed in periods P3 and P4. To clarify the Spanish electricity market, in terms of selling the excess energy to the grid at a price determined by such electricity market, Figure 9 shows an example for an $870 \mathrm{kWp}$ PV installation, 1000 ha aggregated crop area, $40 \mathrm{~m}$ aquifer depth and $1500 \mathrm{~m}^{3} /$ ha crop water need. Energy demanded by the crop, surplus of energy and estimated benefits-excluding and including Spanish taxes-are determined by the different months. Time periods to be applied according to the Spanish electricity market, see Figure 8, are also included.

\begin{tabular}{|c|c|c|c|c|c|c|c|c|c|c|c|c|c|c|c|c|c|}
\hline Hours & $0-8$ & 8 & 9 & 10 & 11 & 12 & 13 & 14 & 15 & 16 & 17 & 18 & 19 & 20 & 21 & 22 & 23 \\
\hline January & P6 & $\mathrm{P} 2$ & $\mathrm{P} 2$ & P1 & P1 & P1 & P2 & P2 & P2 & $\mathrm{P} 2$ & $\mathrm{P} 2$ & P1 & P1 & P1 & $\mathrm{P} 2$ & $\mathrm{P} 2$ & $\mathrm{P} 2$ \\
\hline February & P6 & $\mathrm{P} 2$ & $\mathrm{P} 2$ & P1 & P1 & P1 & $\mathrm{P} 2$ & P2 & $\mathrm{P} 2$ & $\mathrm{P} 2$ & $\mathrm{P} 2$ & P1 & P1 & $\mathrm{P} 1$ & P2 & $\mathrm{P} 2$ & $\mathrm{P} 2$ \\
\hline March & P6 & $\mathrm{P} 4$ & $\mathrm{P} 4$ & $\mathrm{P} 4$ & $\mathrm{P} 4$ & $\mathrm{P} 4$ & $\mathrm{P} 4$ & $\mathrm{P} 4$ & $\mathrm{P} 4$ & P3 & P3 & P3 & P3 & P3 & P3 & P4 & P4 \\
\hline April & P6 & P5 & P5 & P5 & P5 & P5 & P5 & $\mathrm{P} 5$ & P5 & P5 & P5 & P5 & P5 & P5 & P5 & P5 & P5 \\
\hline May & P6 & P5 & P5 & P5 & P5 & P5 & P5 & P5 & P5 & P5 & P5 & P5 & P5 & P5 & P5 & P5 & P5 \\
\hline June (1-15) & P6 & $\mathrm{P} 4$ & $\mathrm{P} 3$ & P3 & P3 & P3 & P3 & P3 & P4 & P4 & P4 & P4 & P4 & P4 & P4 & P4 & P4 \\
\hline June (15-30) & P6 & $\mathrm{P} 2$ & $\mathrm{P} 2$ & $\mathrm{P} 2$ & P1 & P1 & P1 & P1 & P1 & $\mathrm{P} 1$ & P1 & $\mathrm{P} 1$ & $\mathrm{P} 2$ & $\mathrm{P} 2$ & P2 & $\mathrm{P} 2$ & $\mathrm{P} 2$ \\
\hline July & P6 & $\mathrm{P} 2$ & $\mathrm{P} 2$ & $\mathrm{P} 2$ & $\mathrm{P} 1$ & $\mathrm{P} 1$ & P1 & $\mathrm{P} 1$ & P1 & P1 & $\mathrm{P} 1$ & $\mathrm{P} 1$ & $\mathrm{P} 2$ & $\mathrm{P} 2$ & $\mathrm{P} 2$ & $\mathrm{P} 2$ & $\mathrm{P} 2$ \\
\hline Augost & P6 & P6 & P6 & P6 & P6 & P6 & P6 & P6 & P6 & P6 & P6 & P6 & P6 & P6 & P6 & P6 & P6 \\
\hline September & P6 & $\mathrm{P} 4$ & P3 & $\mathrm{P} 3$ & $\mathrm{P} 3$ & $\mathrm{P} 3$ & P3 & P3 & $\mathrm{P} 4$ & $\mathrm{P} 4$ & $\mathrm{P} 4$ & $\mathrm{P} 4$ & P4 & $\mathrm{P} 4$ & $\mathrm{P} 4$ & P4 & P4 \\
\hline October & P6 & P5 & P5 & P5 & P5 & P5 & P5 & P5 & P5 & P5 & P5 & P5 & P5 & P5 & P5 & P5 & $\mathrm{P} 5$ \\
\hline November & P6 & $\mathrm{P} 4$ & $\mathrm{P} 4$ & $\mathrm{P} 4$ & $\mathrm{P} 4$ & $\mathrm{P} 4$ & $\mathrm{P} 4$ & $\mathrm{P} 4$ & P4 & P3 & P3 & P3 & P3 & P3 & P3 & P4 & P4 \\
\hline December & P6 & P2 & P2 & P1 & P1 & P1 & P2 & P2 & $\mathrm{P} 2$ & P2 & P2 & P1 & P1 & P1 & P2 & P2 & $\mathrm{P} 2$ \\
\hline
\end{tabular}

Figure 8. Description of electricity rates for different time periods in the Spanish electricity system.
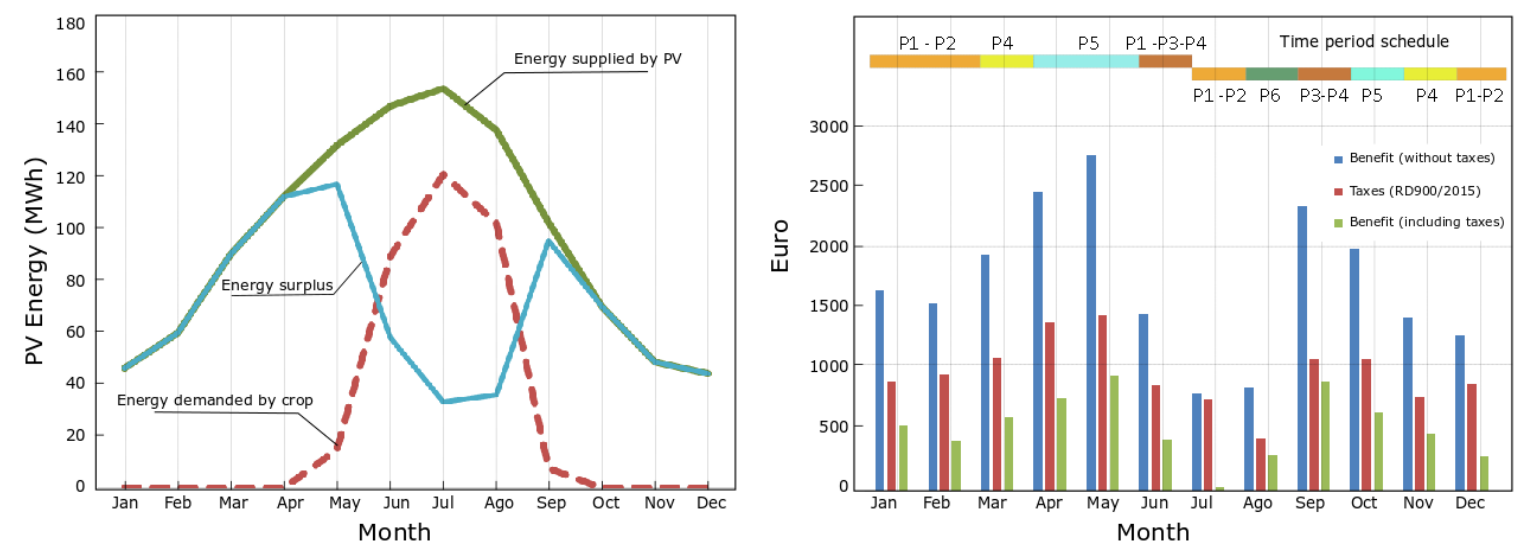

Figure 9. Example of PV generation and surplus of energy. Costs and benefits for the Spanish electricity system.

\section{Results and Discussion}

According to the proposed methodology described in Section 2, the case study is analyzed from a multidimensional perspective with the goals of reducing the intense dependence on fossil fuels, increasing the integration of solar solutions and preserving the aquifer to avoid future lower phreatic levels that would require more energy resources and thus relevant economic efforts. Furthermore, PV power plants connected to the grid can give farmers additional benefits through net-metering scenarios and annual energy surpluses.

\subsection{PV Installations Connected to the Grid: Surplus of Annual Energy}

Depending on the agronomic management of irrigation, the amount of water demanded by certain crops, the climatic conditions, and the state of the soil, the energy required by crops can vary considerably. As previously discussed, most crops require irrigation during specific periods of the year and their demand can be considered as seasonal. For example, for the case study, the months 
are limited to May, June, July, August, and September. Therefore, an important part of the potentially generated annual power is initially wasted. Under this hypothesis, the energy generated for the case study has been quantified-based on the selected PV configuration and the corresponding 1500 and $3000 \mathrm{~m}^{3} /$ ha crop water needs, which represents vineyard crops and a mosaic of vegetation and vineyard for typical areas of the case study. Figure 10 shows the surplus energy gradient based on the surface in hectares and the aquifer depth for the different PV configurations summarized in Figure 7. As shown in these results, greater depth aquifer and greater crop water need would imply more power required by the system, and consequently, the potential annual generated energy will be higher. This is due to the fact that both parameters have a relevant influence on the preliminary estimation of the PV solar pumping installation. Nevertheless, the investments are related to size of the PV power plant, and subsequently, the higher the PV system the higher the annual profits. A more detailed economic analysis, including investments, should be conducted to estimate the best solution. A recent detailed economic analysis carried out by the authors can be found in [59].
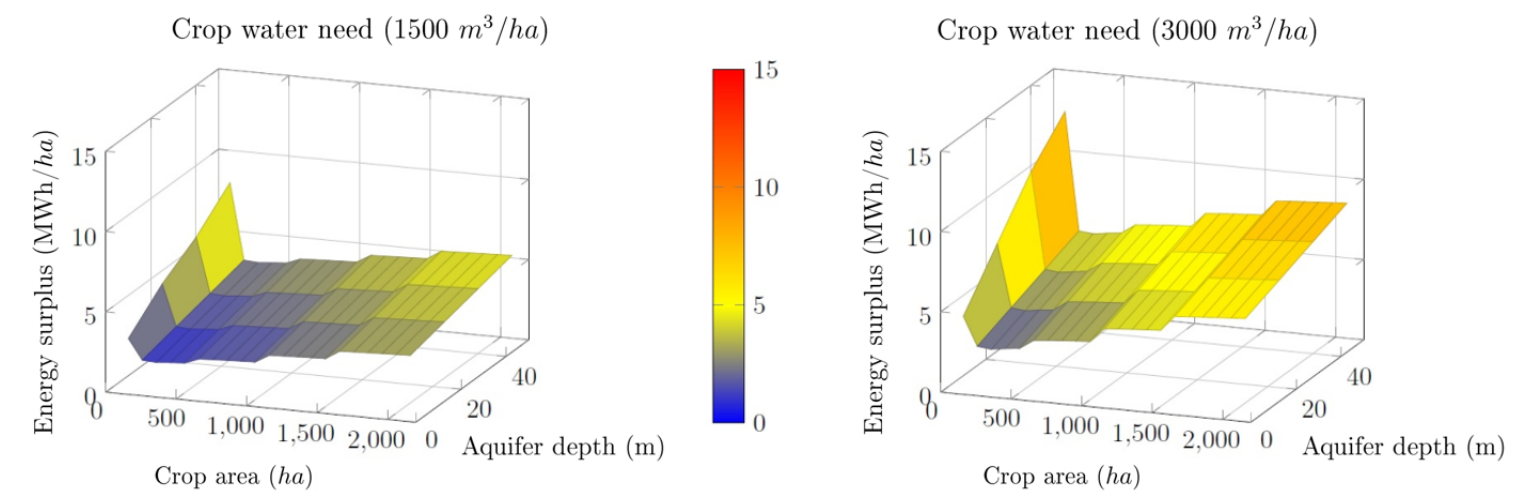

Figure 10. PV installation connected to the grid: annual surplus energy estimation examples (1500 $\mathrm{m}^{3} /$ ha and $3000 \mathrm{~m}^{3} /$ ha).

\subsection{Grid Injection from PV Systems into the Grid: Net-Metering Schemes}

Firstly, and from the annual surplus energy estimation examples depicted in Figure 10, a preliminary estimation of annual benefits can be determined by considering the current Spanish legislation-aimed at promoting net-metering policies-but excluding current taxes on electrical generation summarized in Tables 1-3. With this aim, Figure 11 shows annual estimated economic returns provided by the corresponding PV installations previously determined and summarized in Figure 7. It is important to point out that these benefits are highly dependent on the irrigation profiles required by the crops, and subsequently, they could be different when considering other crops and water needs. Nevertheless, the proposed can be applied to other legislative scenarios.

From these preliminary analyses, the following results estimate the economic compensation of PV facilities under the current Spanish legislation. Figure 12 gives the benefits under the legislation defined in RD900/2015 and the application of the corresponding taxes and charges. The final economic compensation, compared to Figure 11, is reduced for both $1500 \mathrm{~m}^{3} /$ ha and $3000 \mathrm{~m}^{3} / \mathrm{ha}$ cases. The analysis of the results and the comparison between economic return on surplus energy for $1500 \mathrm{~m}^{3} / \mathrm{ha}$ and $3000 \mathrm{~m}^{3} / \mathrm{ha}$, with a law aimed at developing renewable energy and Spanish legislation defined by RD 900/2015, means that only between $40 \%$ and $60 \%$ of economic compensation for the sale of energy is obtained with application of this legislation regarding a net-metering scheme excluding taxes and fees. Subsequently, a PV solar configuration for $3000 \mathrm{~m}^{3} /$ ha allows us to provide between 1.6 and 1.8 times more surplus energy than the $1500 \mathrm{~m}^{3} /$ ha-based solution. For example, an area of 1000 hectares with an aquifer depth of $30 \mathrm{~m}$ and a vineyard crop of $1500 \mathrm{~m}^{3} /$ ha of annual water requirements is estimated to cost 180 Euro/ha (per year) for the sale of energy. The same solution under current Spanish self-consumption legislation would be significantly reduced by up to 81 Euro/ha (per year). 

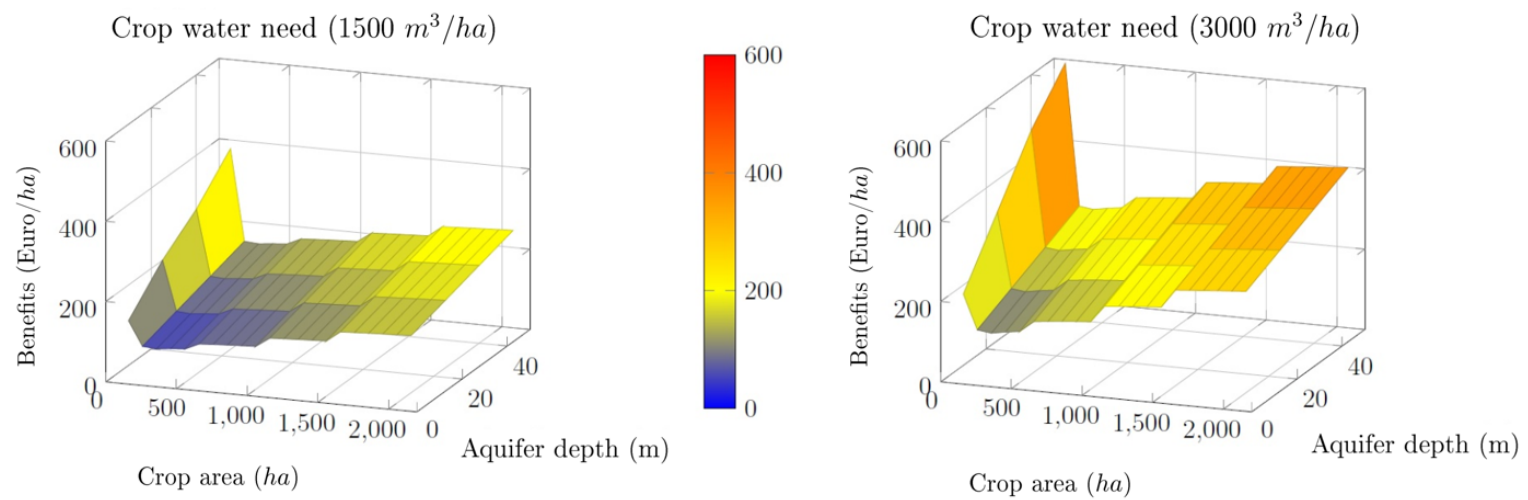

Figure 11. PV installation connected to the grid: annual benefit estimation examples excluding taxes and fees $\left(1500 \mathrm{~m}^{3} /\right.$ ha and $\left.3000 \mathrm{~m}^{3} / \mathrm{ha}\right)$.
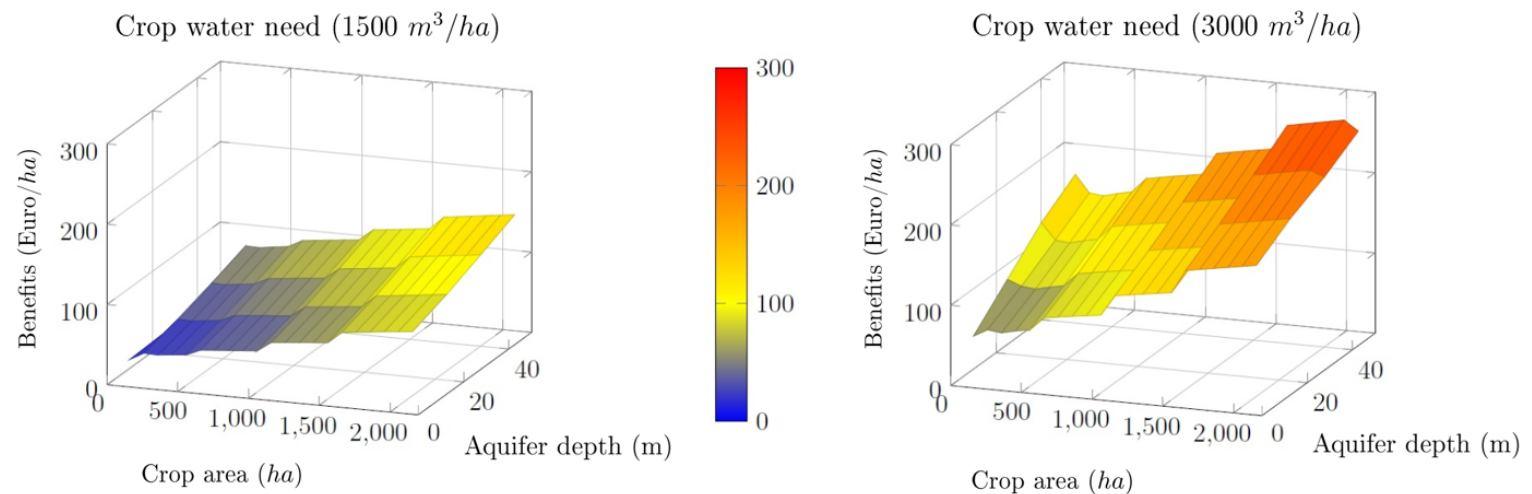

Figure 12. PV installation connected to the grid: annual benefit estimation examples including taxes and fees $\left(1500 \mathrm{~m}^{3} /\right.$ ha and $\left.3000 \mathrm{~m}^{3} / \mathrm{ha}\right)$.

\subsection{PV Integration into Net-Metering Schemes: Aquifer 23 Discussion}

By considering that PV solar installations for pumping groundwater purposes can be used more efficiently under net-metering schemes, significant economic benefits and environmental profits can be provided by these facilities. The proposed PV configurations allow reduction in the energy costs and subsequently the production costs, becoming more competitive without changing the profit margin. In addition, these solutions give rural areas an opportunity to maintain their population and, at the same time, reduce their economic dependency mainly based on subsidies. A remarkable reduction of emissions in the agricultural sector can also be achieved. According to the annual benefit estimation for the self-consumption and net-metering schemes previously described are summarized in Figure 12, it is possible to extrapolate the data to the rest of the aquifer (Aquifer 23). In this way, we consider the point where the concentration of wells is larger: within zones $\mathrm{Z1}$ and Z2, accounting for $58 \%$ of the wells. If communities of irrigators of $800 \mathrm{ha}$, such as an existing one of this size, were connected to the grid, considering the average aquifer depth in those zones, emissions would be reduced in a more than relevant way. As previously discussed, after implementing a PV power plant connected to the grid in a community of irrigators, the economic benefits are highly dependent on the specific crop water need and the aquifer depth, which corresponds to 50,000 to 90,000 Euro in Z1 and 100,000 to 140,000 Euro in $\mathrm{Z} 2$, based on a net-metering scheme excluding taxes and fees; and from 28,000 to 50,000 euros in Z1 and 40,000 to 90,000 euros in Z2 according to current legislation in Spain (RD900/2015). Extrapolating the economic benefits for the entire aquifer, direct benefits to farmers of between 8 and 13 million Euro could be achieved in Z1, and between 3 and 4 million Euro in Z2, in accordance with a preliminary net-metering scheme without taxes and fees. However, with the current legislation in Spain regarding self-consumption and net-metering, between 4 and 8 million Euro in $\mathrm{Z} 1$ and between 1 and 2.5 million 
Euro in $\mathrm{Z} 2$ would be estimated annually. Tables 4 and 5 summarizes the economic benefits from the corresponding net-metering schemes by $\mathrm{Z} 1$ and $\mathrm{Z} 2$ zones, respectively.

Finally, Figure 13 summarizes the analyzed approaches considered in this work and the corresponding advantages from these different perspectives. Presently, to undertake projects and design aid for the promotion of new renewable technologies and energy efficiency in agriculture, the European Union promotes several programs along this line under the European Agricultural Fund for Rural Development (EAFRD), to which is added the Green Fund for Climate [60] for other countries.

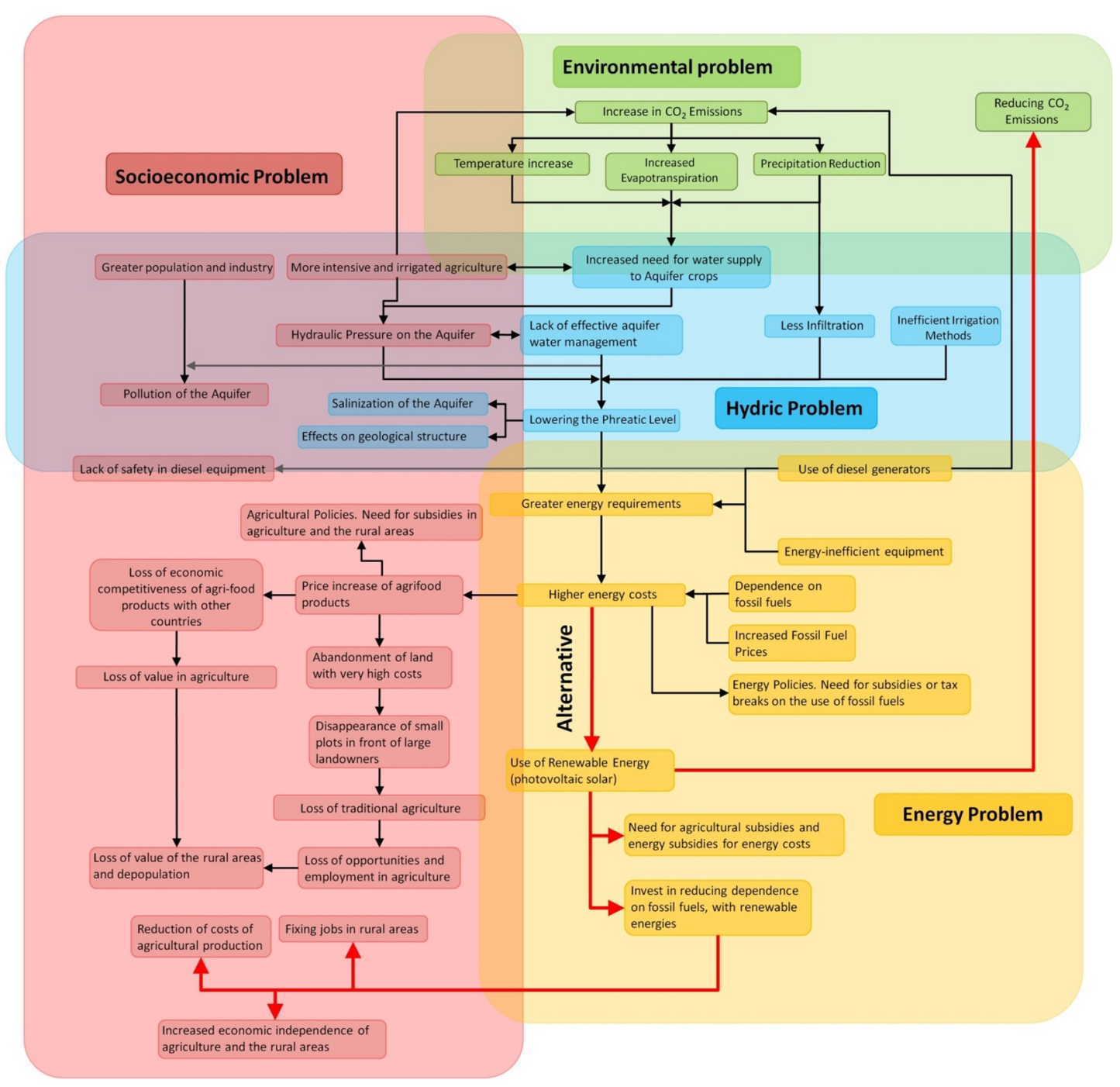

Figure 13. Integrating renewables into net-metering: advantages and multifocused approach.

Table 4. Economic benefits: Z1 zone (159 communities, 800 ha/community).

\begin{tabular}{cccc}
\hline $\begin{array}{c}\text { Crop Water Need } \\
\left(\mathbf{m}^{\mathbf{3}} \mathbf{h a} \mathbf{h}\right)\end{array}$ & $\begin{array}{c}\text { Area } \\
\text { (ha) }\end{array}$ & $\begin{array}{c}\text { Economic Benefit Excluding } \\
\text { Taxes (Euro) }\end{array}$ & $\begin{array}{c}\text { Economic Benefit Including } \\
\text { Taxes (Euro) }\end{array}$ \\
\hline \multirow{2}{*}{1500} & 440 (Aggregated Area) & 52,800 & 26,800 \\
& 127,200 (Global Area) & $8,395,134$ & $4,547,364$ \\
3000 & 440 (Aggregated Area) & 88,000 & 50,600 \\
& 127,200 (Global Area) & $13,991,890$ & $8,045,337$ \\
\hline
\end{tabular}


Table 5. Economic benefits: Z2 zone (28 communities, 800 ha/community).

\begin{tabular}{cccc}
\hline $\begin{array}{c}\text { Crop Water Need } \\
\left(\mathbf{m}^{\mathbf{3}} \mathbf{h} \mathbf{h}\right)\end{array}$ & $\begin{array}{c}\text { Area } \\
\text { (ha) }\end{array}$ & $\begin{array}{c}\text { Economic Benefit Excluding } \\
\text { Taxes (Euro) }\end{array}$ & $\begin{array}{c}\text { Economic Benefit Including } \\
\text { Taxes (Euro) }\end{array}$ \\
\hline \multirow{2}{*}{1500} & Community Area (616) & 105,336 & 47,432 \\
& Global Area (27,400) & $2,955,596$ & $1,330,883$ \\
3000 & Community Area (616) & 142,912 & 94,248 \\
& Global Area (27,400) & $4,009,932$ & $2,644,481$ \\
\hline
\end{tabular}

\section{Conclusions}

The integration of PV solar installations connected to the grid into the agriculture sector is proposed and evaluated under net-metering and self-consumption scenarios. This solar resource allows us to decrease emissions and fossil fuel dependence and improve economic benefits from a surplus energy sale standpoint. This multifocused analysis is an exportable and scalable solution that can be applied in different locations depending on different parameters, such as crop water need, aquifer depth, and grouped crop areas. A Spanish aquifer highly overexploited over the decades is used to evaluate the proposed methodology. Different surplus energy sale scenarios are analyzed according to the typical crops in this location and the corresponding annual water requirements and common grouping areas. In this way, relevant annual benefits are estimated in grouped areas of 800 ha, accounting for 50,000 to 140,000 euros/year in a net-metering situation excluding taxes and fees; and 28,000 to 90,000 euros under current Spanish regulations. Regardless of the level of grouped areas, PV power plants interconnected with the grid for the use of surplus energy could generate nonnegligible global revenues: between 10 and 18 million euros/year with a legislation prone to net-metering and between 5 and 10 million euros/year under the current Spanish legislation framework. Therefore, global policies focused on water management and efficient agricultural objectives should be promoted for massive integration of such renewables into the agriculture sector. More specifically, energy policies in terms of net-metering and/or self-consumption schemes that provide regulatory stability to this energy model in agriculture are required by the sector.

Author Contributions: Conceptualization, A. M.-G.; Formal analysis, J.M.S.-L.; Funding acquisition, M.S.G.-C.; Investigation, A.R.-A.; Project administration, A.R.-A.; Validation, M.S.G.-C.; Writing—original draft, A.M.-G. and J.M.S.-L.; Writing-review and editing, A.M.-G.

Funding: This research was funded by the research project TIN2017-86647-P from the Spanish Ministry of Science and Innovation (including FEDER funds), and the Seneca Foundation 19882-GERM-15.

Conflicts of Interest: The authors declare no conflict of interest.

\section{References}

1. United Nations. Session of the Conference of the Parties. 21st Yearly Session. Approval of the Paris Agreement; United Nations Climate Change Conference; United Nations: New York, NY, USA, 2015.

2. Official Journal of the European Union. Directive 2009/28/CE of the European Parliament and of the Council of 23 April 2009, On the Promotion of the Use of Energy from Renewable Sources; 140/16; United Nations: New York, NY, USA, 2009.

3. Villamayor-Tomas, S. Chapter 2.1.3-The Water-Energy Nexus in Europe and Spain: An Institutional Analysis From the Perspective of the Spanish Irrigation Sector. In Competition for Water Resources; Ziolkowska, J.R., Peterson, J.M., Eds.; Elsevier: Berlin, Germany, 2017; pp. 105-122.

4. Glasnovic, Z.; Margeta, J. A model for optimal sizing of photovoltaic irrigation water pumping systems. Sol. Energy 2007, 81, 904-916. [CrossRef]

5. Abu-Aligh, M. Design of photovoltaic water pumping system and compare it with diesel powered pump. Jordan J. Mech. Ind. Eng. 2011, 5, 273-280.

6. Foster, R.; Cota, A. Solar water pumping advances and comparative economics. Energy Procedia 2014, 57, 1431-1436. [CrossRef] 
7. Cuadros, F.; López-Rodríguez, F.; Marcos, A.; Coello, J. A procedure to size solar-powered irrigation (photoirrigation) schemes. Sol. Energy 2004, 76, 465-473. [CrossRef]

8. Odeh, I.; Yohanis, Y.; Norton, B. Influence of pumping head, insolation and PV array size on PV water pumping system performance. Sol. Energy 2006, 80, 51-64. [CrossRef]

9. Meah, K.; Ula, S.; Barrett, S. Solar photovoltaic water pumping-Opportunities and challenges. Renew. Sustain. Energy Rev. 2008, 12, 1162-1175.

10. Kelley, L.C.; Gilbertson, E.; Sheikh, A.; Eppinger, S.D.; Dubowsky, S. On the feasibility of solar-powered irrigation. Renew. Sustain. Energy Rev. 2010, 14, 2669-2682. [CrossRef]

11. Dursun, M.; Ozden, S. Application of Solar Powered Automatic Water Pumping in Turkey. Int. J. Comput. Electr. Eng. 2012, 4, 161. [CrossRef]

12. Rao, M.M.; Sahu, M.K.; Subudhi, P.K. Pv based water pumping system for agricultural sector. Mater. Today Proc. 2018, 5, 1008-1016.

13. Zahab, E.E.A.; Zaki, A.M.; El-sotouhy, M.M. Design and control of a standalone PV water pumping system. J. Electr. Syst. Inf. Technol. 2017, 4, 322-337. [CrossRef]

14. Singh, B.; Sharma, U.; Kumar, S. Standalone photovoltaic water pumping system using induction motor drive with reduced sensors. IEEE Trans. Ind. Appl. 2018, 54, 3645-3655. [CrossRef]

15. Binshad, T.; Vijayakumar, K.; Kaleeswari, M. PV based water pumping system for agricultural irrigation. Front. Energy 2016, 10, 319. [CrossRef]

16. González, A.; Riba, J.R.; Rius, A.; Puig, R. Optimal sizing of a hybrid grid-connected photovoltaic and wind power system. Appl. Energy 2015, 154, 752-762. [CrossRef]

17. Meah, K.; Fletcher, S.; Ula, S. Solar photovoltaic water pumping for remote locations. Renew. Sustain. Energy Rev. 2008, 12, 472-487. [CrossRef]

18. Langarita, R.; Chóliz, J.S.; Sarasa, C.; Duarte, R.; Jiménez, S. Electricity costs in irrigated agriculture: A case study for an irrigation scheme in Spain. Renew. Sustain. Energy Rev. 2017, 68, 1008-1019. [CrossRef]

19. Marano, V.; Rizzo, G.; Tiano, F.A. Application of dynamic programming to the optimal management of a hybrid power plant with wind turbines, photovoltaic panels and compressed air energy storage. Appl. Energy 2012, 97, 849-859. [CrossRef]

20. Maheshwari, Z.; Ramakumar, R. Smart Integrated Renewable Energy Systems (SIRES): A Novel Approach for Sustainable Development. Energies 2017, 10, 1145. [CrossRef]

21. Bacha, S.; Picault, D.; Burger, B.; Etxeberria-Otadui, I.; Martins, J. Photovoltaics in Microgrids: An Overview of Grid Integration and Energy Management Aspects. IEEE Ind. Electron. Mag. 2015, 9, 33-46. [CrossRef]

22. Guerrero, J.M.; Blaabjerg, F.; Zhelev, T.; Hemmes, K.; Monmasson, E.; Jemei, S.; Comech, M.P.; Granadino, R.; Frau, J.I. Distributed generation: Toward a new energy paradigm. IEEE Ind. Electron. Mag. 2010, 1, 52-64. [CrossRef]

23. Boehner, V.; Franz, P.; Hanson, J.; Gallart, R.; Martínez, S.; Sumper, A.; Girbau-Llistuella, F. Smart grids for rural conditions and e-mobility-Applying power routers, batteries and virtual power plants. In Proceedings of the International Council on Large Electric Systems CIGRE, Paris, France, 21-26 August 2016; pp. 1-9.

24. Alstone, P.; Gershenson, D.; Kammen, D.M. Decentralized energy systems for clean electricity access. Nat. Clim. Chang. 2015, 5, 305-314. [CrossRef]

25. Kou, L.; Sheng, W.; Wang, J.; Liang, Y.; Song, Q. Evaluation on the application mode of distributed generation. In Proceedings of the 2012 China International Conference on Electricity Distribution (CICED), Shanghai, China, 10-14 September 2012; pp. 1-5.

26. Girbau-Llistuella, F.; Sumper, A.; Díaz-González, F.; Sudrià-Andreu, A.; Gallart-Fernández, R. Local performance of the smart rural grid through the local energy management system. In Proceedings of the 7th International Conference on Modern Power Systems, Napoca, Romania, 6-9 June 2017; pp. 1-6.

27. Bassi, N. Solarizing groundwater irrigation in India: A growing debate. Int. J. Water Resour. Dev. 2018, 34, 132-145, [CrossRef]

28. Sajjad, I.A.; Manganelli, M.; Martirano, L.; Napoli, R.; Chicco, G.; Parise, G. Net-Metering Benefits for Residential Customers: The Economic Advantages of a Proposed User-Centric Model in Italy. IEEE Ind. Appl. Mag. 2018, 24, 39-49. [CrossRef]

29. Christoforidis, G.C.; Panapakidis, I.P.; Papadopoulos, T.A.; Papagiannis, G.K.; Koumparou, I.; Hadjipanayi, M.; Georghiou, G.E. A Model for the Assessment of Different Net-Metering Policies. Energies 2016, 9, 262. [CrossRef] 
30. Romero-Rubio, C.; Andrés-Díaz, J.R. Spanish electrical system: Effect of energy reform in the development of distributed generation. In Proceedings of the 18th International Congress on Project Engineering, Alcañiz, Spain, 16-18 July 2014.

31. Ministry of Industry. Royal Decree 900/2015, of October 9, Which Regulates the Administrative, Technical and Economic Conditions for the Supply of Electric Energy with Self-Consumption and Production with Self-Consumption; Technical Report 243; State Official Newsletter BOE: Madrid, Spain, 2015. (In Spanish)

32. Arboleya, P.; Gonzalez-Moran, C.; Coto, M.; Garcia, J. Self-supply and net balance: The Spanish scenario. In Proceedings of the 2013 International Conference on New Concepts in Smart Cities: Fostering Public and Private Alliances (SmartMILE), Gijon, Spain, 11-13 December 2013; pp. 1-6.

33. Rubio-Aliaga, A.; Socorro, G.C.M.; Molina-Garcia, A.; Sánchez-Lozano, J. Geographic Information System for Optimization and Integration of Photovoltaic Solar Energy in Agricultural Areas with Energy Deficiency and Water Scarcity; Springer: Cham, Switzerland, 2017; pp. 181-197.

34. De Castro, M.; Martín-Vide, J.; Alonso, S. Preliminary Evaluation of the Impacts in Spain due to Climate Change; Ministry of Environment: Madrid, Spain, 2005. (In Spanish)

35. Chaturvedi, V.; Hejazi, M.I.; Edmonds, J.A.; Clarke, L.E.; Kyle, G.P.; Davies, E.; Wise, M.A.; Calvin, K.V. Climate Policy Implications for Agricultural Water Demand; Pacific Northwest National Laboratory Technical Report PNNL-22356; US Department of Energy: Richland, WA, USA, 2013.

36. El Moustaine, R.; Chahlaoui, A.; Rour, E. Relationships between the physico-chemical variables and groundwater biodiversity: A case study from meknes area, Morocco. Int. J. Conserv. Sci. 2014, 5, $203-214$.

37. Capone, R.; Debs, P.; El Bilali, H.; Cardone, G.; Lamaddalena, N. Water footprint in the Mediterranean food chain: implications of food consumption patterns and food wastage. Int. J. Nutr. Food Sci. 2014, 3, $26-36$. [CrossRef]

38. Closas, A.; Rap, E. Solar-based groundwater pumping for irrigation: Sustainability, policies, and limitations. Energy Policy 2017, 104, 33-37. [CrossRef]

39. Ruiz-Pulpón, A. Irrigation and sustainable management of water resources in the Guadiana basin: Territorial proposal prior to decision-making. Geogr. Res. 2006, 40, 183-200. (In Spanish)

40. Iglesias-Martínez, E. Economics and Sustainable Management of Groundwater: La Mancha Occidental Aquifer. Ph.D. Thesis, Technical School of Agricultural Engineers, Polytechnic University of Madrid (UPM), Madrid, Spain, 2001. (In Spanish)

41. Bosque-Maurel, J. Water as a scarce resource and its problems in Spain. Geogr. Res. 2008, 69, $453-493$. (In Spanish)

42. Varela-Ortega, C.; Blanco-Gutiérrez, I.; Swartz, C.H.; Downing, T.E. Balancing groundwater conservation and rural livelihoods under water and climate uncertainties: An integrated hydro-economic modeling framework. Glob. Environ. Chang. 2011, 21, 604-619. Special Issue on The Politics and Policy of Carbon Capture and Storage. [CrossRef]

43. Faysse, N.; Hartani, T.; Frija, A.; Tazekrit, I.; Zairi, C.; Challouf, A. Agricultural Use of Groundwater and Management Initiatives in the Maghreb: Challenges and Opportunities for Sustainable Aquifer Exploitation; Technical Report; African Development Bank: Abidjan, Côte d'Ivoire, 2011.

44. Fernández-García, I.; Rodríguez-Díaz, J.; Camacho-Poyato, E.; Montesinos, P.; Berbel, J. Effects of modernization and medium term perspectives on water and energy use in irrigation districts. Agric. Syst. 2014, 131, 56-63. [CrossRef]

45. Bouwer, H. Integrated water management for the 21st century: Problems and solutions. J. Irrig. Drain. Eng. 2002, 128, 193-202. [CrossRef]

46. García-Cárdenas, R. Methodology for the Quantification and Control of Subsidence in Large Territorial Areas. Application to the Case of the Guadalentín Basin, Lorca (Murcia). Ph.D. Thesis, Department of Civil Engineering, San Antonio Catholic University of Murcia (UCAM), Murcia, Spain, 2017. (In Spanish)

47. Carpintero, O.; Naredo, J. On the evolution of energy balances in Spanish agriculture, 1950-2000. J. Agric. Rural Hist. 2006, 16, 531-554. (In Spanish)

48. Ghoneim, A. Design optimization of photovoltaic powered water pumping systems. Energy Convers. Manag. 2006, 47, 1449-1463. [CrossRef]

49. Chandel, S.; Naik, M.N.; Chandel, R. Review of solar photovoltaic water pumping system technology for irrigation and community drinking water supplies. Renew. Sustain. Energy Rev. 2015, 49, 1084-1099. [CrossRef] 
50. Sumpsi, J. The crisis of modern agriculture. Agric. Soc. 1982, 25, 185-193. (In Spanish)

51. García-Álvarez, M.T.; Cabeza-García, L.; Soares, I. Assessment of energy policies to promote photovoltaic generation in the European Union. Energy 2018, 151, 864-874. [CrossRef]

52. Sauhats, A.; Zemite, L.; Petrichenko, L.; Moshkin, I.; Jasevics, A. Estimating the Economic Impacts of Net Metering Schemes for Residential PV Systems with Profiling of Power Demand, Generation, and Market Prices. Energies 2018, 11, 3222. [CrossRef]

53. Masson, G.; Briano, J.I.; Baez, M.J. A Methodology for the Analysis of Pv Self-Consumption Policies; Technical Report Task 1, Report IEA-PVPS T1-28; International Energy Agency: Paris, France, 2016.

54. Sobor, I. Photovoltaic pump system design for small irrigation. In Proceedings of the 2017 International Conference on Electromechanical and Power Systems (SIELMEN), Iasi, Romania, 11-13 October 2017; pp. 315-320.

55. Marchi, B.; Pasetti, M.; Zanoni, S.; Zavanella, L. The Italian reform of electricity tariffs for non household customers: The impact on distributed generation and energy storage. In Proceedings of the XXII Summer School Francesco Turco-Industrial Systems Engineering, At Palermo, Italy, 13-15 September 2017; pp. 1-7.

56. Berbel, J.; Expósito, A.; Gutiérrez-Martín, C.; Mateos, L. Effects of the Irrigation Modernization in Spain 2002-2015. Water Resour. Manag. 2019, 33, 1835-1849. [CrossRef]

57. Moreno, M.M.; Gutiérrez, J.L.; Cortina, L.M. Hydrogeological characteristics and groundwater evolution of the Western La Mancha unit: The influence of the wet period 2009-2011. Boletin Geológico y Minero 2012, 123, 91-108. (In Spanish)

58. Sanz, G.L. Irrigated agriculture in the Guadiana River high basin (Castilla-La Mancha, Spain): Environmental and socioeconomic impacts. Agric. Water Manag. 1999, 40, 171-181. [CrossRef]

59. Rubio-Aliaga, Á.; García-Cascales, M.; Sánchez-Lozano, J.; Molina-García, A. Multidimensional analysis of groundwater pumping for irrigation purposes: Economic, energy and environmental characterization for PV power plant integration. Renew. Energy 2019, 138, 174-186. [CrossRef]

60. Cui, L.; Huang, Y. Exploring the Schemes for Green Climate Fund Financing: International Lessons. World Dev. 2018, 101, 173-187. [CrossRef]

(C) 2019 by the authors. Licensee MDPI, Basel, Switzerland. This article is an open access article distributed under the terms and conditions of the Creative Commons Attribution (CC BY) license (http:/ / creativecommons.org/licenses/by/4.0/). 